\title{
TÌM HIỂU HIỆN TƯợNG DI CƯ QUỐC TẾ Ở NGƯờI CƠ HO HUYỆN LẠC DƯONG, TỈNH LÂM ĐỒNG
}

\author{
Võ Thuấn ${ }^{\mathrm{a}^{*}}$, Trần Thị Minh Phương ${ }^{\mathrm{a}}$ \\ ${ }^{a}$ Khoa Công tác Xã hội, Truò̀ng Đại học Đà Lạt, Lâm Đồng, Việt Nam \\ *Tác giả liên hệ: Email: thuanv@dlu.edu.vn \\ Lịch sử bài báo \\ Nhận ngày 13 tháng 03 năm 2019 \\ Chỉnh sửa lần 01 ngày 08 tháng 04 năm 2019 | Chỉnh sửa lần 02 ngày 03 tháng 05 năm 2019 \\ Chấp nhận đăng ngày 19 tháng 07 năm 2019
}

\section{Tóm tắt}

Trong bối cảnh hội nhập và toàn cầu hóa, di cu quốc tế đã trở thành một trong nhũng vấn đề lớn của thời đại ngày nay. Chua có thời kỳ nào trong lịch sử nhân loại vấn đề di cu lai diễn ra với quy mô lớn, tính chất phức tạp, và có nhiều tác động nhu hiện nay. Có nhiều nguyên nhân thúc đẩy quá trình di cu, bao gồm quy luật cung - cầu về súc lao động, sự chênh lệch về mức sống, thu nhập, điều kiện làm việc, an sinh, dịch vu xã hội, huơơng thu văn hóa... Trong bài viết này, trước tiên chúng tôi tập trung tìm hiểu nguồn gốc, các loại hình của quá trình di cu ra nuớc ngoài của nguời Co Ho ở huyện Lac Duơng, tỉnh Lâm Đồng; Thứ hai là mô tả thực trạng di cu ra nước ngoài của họ; và Thứ ba là phân tích vai trò của di cu ra nuớc ngoài trong đời sống gia đình và cộng đồng của nguời Co Ho ở huyện Lạc Duoong, tỉnh Lâm Đồng.

Từ khóa: Di cư; Di cư quốc tế; Người di cư.

DOI: http://dx.doi.org/10.37569/DalatUniversity.9.3.549(2019)

Loại bài báo: Bài báo nghiên cứu gốc có bình duyệt

Bản quyền @ 2019 (Các) Tác giả.

Cấp phép: Bài báo này được cấp phép theo CC BY-NC-ND 4.0 


\title{
INTERNATIONAL MIGRATION OF CO HO PEOPLE OF LACDUONG DISTRICT, LAMDONG PROVINCE
}

\author{
Vo Thuan ${ }^{\text {**, Tran Thi Minh Phuonga }}$ \\ ${ }^{a}$ The Faculty of Social Work, Dalat University, Lamdong, Vietnam \\ *Coressponding author: Email: thuanv@dlu.edu.vn
}

\section{Article history}

Received: March $13^{\text {th }}, 2019$

Received in revised form $\left(1^{\text {st }}\right)$ : April $8^{\text {th }}, 2019 \mid$ Received in revised form $\left(2^{\text {nd }}\right)$ : May $3^{\text {rd }}, 2019$

Accepted: July $19^{\text {th }}, 2019$

\begin{abstract}
In the context of integration and globalization, international migration has become one of the major problems of this era. There has not been a period in history where the issue of migration has occurred on such a large scale and been so consequential. There are many causes for the migration process, including the law of supply and demand for labor, the difference in living standards, income, working conditions, welfare, social services, cultural enjoyment, etc. In this article, we will first focus on understanding the origin and types of overseas migration of the Co Ho of Lacduong district, Lamdong province. Then we will describe their overseas migration status and lastly, analyze the role of migration in family and community life.
\end{abstract}

Keywords: Migrants; Migration; International migration.

DOI: http://dx.doi.org/10.37569/DalatUniversity.9.3.549(2019)

Article type: (peer-reviewed) Full-length research article

Copyright $(92019$ The author(s).

Licensing: This article is licensed under a CC BY-NC-ND 4.0 


\section{1. ĐặT VẤN ĐỀ}

Trong bối cảnh hội nhập và toàn cầu hóa, di cư quốc tế đã trở thành một trong những vấn đề lớn của thời đại ngày nay. Chưa có thời kỳ nào trong lịch sử nhân loại vấn đề di cư lại diễn ra với quy mô lớn, tính chất và có nhiều tác động như hiện nay. Đặc biệt từ năm 2015 đến nay có cuộc khủng hoảng người nhập cư vào Châu Âu do sự kết hợp của người nhập cư và người tị nạn kinh tế sang Liên minh Châu Âu từ các khu vực như Châu Phi, Trung Đông, và Balkan. Hơn nữa, chính sách cực kỳ cứng rắn hạn chế nhập cư của Tổng thống Mỹ Donald Trump hiện nay cũng tác động đến tình hình di cư quốc tế. Theo ước tính của Tổ chức Di cư Quốc tế (IOM), có gần 250 triệu người đang sống và làm việc ngoài đất nước của mình, chiếm khoảng $3.3 \%$ dân số toàn cầu. Các kết quả nghiên cứu đều chỉ ra rằng: Di cư quốc tế là xu hướng tất yếu; Di cư quốc tế có tác động tích cực trên nhiều mặt kinh tế, xã hội, văn hóa đối với chính người di cư và gia đình họ, cộng đồng, xã hội ở nơi đi và cả ở nơi đến. Bên cạnh đó cũng có một số tác động không mong muốn ở cả nơi đi và nơi đến, nhất là tác động của loại hình di cư tị nạn hay buôn bán người. Cần có những biện pháp, chính sách phù hợp nhằm giảm thiểu những tác động này (Cục lãnh sự - Bộ Ngoại giao \& IOM - OIM, 2017).

Theo số liệu của các cơ quan chức năng, hiện cộng đồng người Việt Nam ở nước ngoài có khoảng hơn bốn triệu người đang sinh sống, học tập và làm việc tại 103 quốc gia, vùng lãnh thổ. Trong đó hơn $80 \%$ ở tại các nước công nghiệp phát triển; 3.2 triệu người có quy chế cư trú dài hạn (Cục Lãnh sự - Bộ Ngoại giao, Liên minh Châu Âu, \& Tổ chức di cư Quốc tế IOM, 2011). Có nhiều nguyên nhân thúc đẩy di cư, bao gồm quy luật cung cầu về sức lao động, sự chênh lệch về mức sống, thu nhập, điều kiện làm việc, an sinh, dịch vụ xã hội, hưởng thụ văn hóa... Tại Việt Nam, sự gia tăng về quy mô di cư quốc tế gắn liền với những biến đổi kinh tế, xã hội, văn hóa nhanh chóng qua hơn 30 năm đổi mới. Phát triển kinh tế xã hội và di cư luôn đi cùng nhau, di cư vừa là động lực thúc đẩy vừa là kết quả của sự phát triển kinh tế xã hội. Các hình thái di cư ở nước ta ngày càng đa dạng, quy mô di cư ngày càng tăng, đòi hỏi cần được quan tâm xem xét trong nghiên cứu và chính sách.

Có nhiều cơ quan, tổ chức, và nhà nghiên cứu quan tâm nghiên cứu về vấn đề di cư khá phong phú và đa dạng. Các nghiên cứu xoay quanh vấn đề về tổng quan, tình hình, thực trạng di cư, các khía cạnh tác động kinh tế xã hội cũng như thách thức đối với quá trình phát triển. Sự hội nhập của người di cư tại nơi ở mới, những mối liên hệ thông qua mạng lưới giữa họ với nhau và với người thân ở lại quê nhà. Các nghiên cứu có quy mô lớn nhỏ khác nhau, liên quan đến các dòng di cư quốc tế và di cư trong nước, được nhìn nhận trên diện rộng. Tuy nhiên, ở Việt Nam có rất ít các nghiên cứu về di cư quốc tế dành cho người đồng bào dân tộc thiểu số với những ảnh hưởng, tác động và vai trò của họ đối với quê nhà.

Bài viết này hy vọng sẽ làm sáng tỏ những phương pháp, nội dung cần thiết trong nghiên cứu thực nghiệm về thực trạng và vai trò của di cư ra nước ngoài, đồng thời có thể có ý nghĩa thực tiễn cho cộng đồng, địa phương để có những chính sách phù hợp đối với vấn đề di cư cho đồng bào dân tộc thiểu số. Phương pháp nghiên cứu chủ yếu là sự kết hợp phương pháp nghiên cứu định tính (quan sát, phỏng vấn sâu, thảo luận 
nhóm nhỏ), phương pháp phân tích tài liệu thứ cấp. Một số khái niệm sau đây là công cụ để nghiên cứu tình hình di cư ra nước ngoài.

- $\quad D i$ cu: Trong quá trình phát triển, di cư là một hiện tượng khá phức tạp và không dễ đo lường. Khái niệm này khác nhau đối với các nhà nghiên cứu, các công trình của họ và đương nhiên không nhất thiết phải thống nhất theo một định nghĩa duy nhất. Tùy theo vấn đề, mục đích và địa bàn, nhà nghiên cứu có thể xây dựng, xác định khái niệm di cư theo các tiêu chí thời gian, không gian, khoảng cách địa lý, và các nhân tố xã hội khác. Một cách hiểu chung nhất, di cư là sự di dời đến một miền hay một nước khác sinh sống. Có hai hình thức di cư chủ yếu là di cư nội địa và di cư quốc tế, trong đó, di cư nội địa là sự di chuyển trong phạm vi một nước, di cư quốc tế nghĩa là sự di chuyển từ quốc gia này tới quốc gia khác. Tuy nhiên, việc xem xét di cư chỉ đơn thuần là sự chuyển đi hay chuyển đến của một cá nhân sẽ dẫn đến sự hiểu sai bản chất kinh tế - xã hội của hiện tượng này và sẽ không giúp phân tích được nguyên nhân và hậu quả của di cư. Di cư là một quá trình mà theo thời gian, nó làm thay đổi bản chất các điều kiện ban đầu đã làm nảy sinh di cư cùng với biến đổi trong nhận thức và ý định ban đầu của người di cư (Đặng, 2009).

- Người di cu: Vẫn chưa có một định nghĩa được chấp nhận chung nào trên cấp độ quốc tế về "người di cư". Thuật ngữ "người di cư" thường được hiểu bao hàm mọi trường hợp di cư tự nguyện do cá nhân tự quyết định vì lý do "tiện ích cá nhân" mà không có sự can thiệp của nhân tố bắt buộc bên ngoài. Nó cũng được áp dụng đối với những người di chuyển tới một nước hoặc vùng lãnh thổ khác để cải thiện điều kiện xã hội và vật chất của họ, và cũng như mở tương lai cho họ và gia đình. Liên Hợp quốc định nghĩa người di cư là một cá nhân đã cư trú tại một nước hơn một năm, bất kể người đó di cư tự nguyện, hay theo cách được phép hay trái phép. Với một định nghĩa như vậy, những người đi lại với thời gian ngắn hơn như khách du lịch, thương nhân không được coi là người di cư. Tuy nhiên cách sử dụng chung bao gồm cả những người di cư ngắn hạn, như lao động nông nghiệp theo thời vụ, những người đi lại trong những thời gian ngắn để trồng trọt và thu hoạch sản phẩm nông nghiệp (Perruchoud \& Cross, 2011).

- Di cu quốc tế: Sự di chuyển của những người rời nước gốc hoặc nước cư trú thường xuyên để tạo lập cuộc sống mới tại nước khác, kể cả tạm thời hoặc lâu dài. Vì thế họ phải vượt qua một biên giới quốc tế (Perruchoud \& Cross, 2011). Trong bài viết này, người Cơ Ho ở Lạc Dương, Lâm Đồng di cư ra nước ngoài được xem là người di cư quốc tế. 


\section{MỘT SỐ KẾT QUẢ NGHIÊN CỬU VÀ PHÁT HIỆN}

\subsection{Tóm tắt quá trình di cư quốc tế của người Cơ Ho ở Lạc Dương, Lâm Đồng}

Huyện Lạc Dương, tỉnh Lâm Đồng là vùng đất cư trú lâu đời của người đồng bào dân tộc thiểu số Cơ Ho. Người Pháp, trong quá trình xâm lược các nước thuộc địa Đông Dương, mong muốn tìm kiếm một vùng đất nghỉ dưỡng cho công chức và binh lính Pháp với khí hậu ôn đới tương tự như chính nước Pháp ở Châu Âu, đã khám phá ra Cao nguyên Lâm Viên (trong đó có huyện Lạc Dương, Lâm Đồng). Đồng bào dân tộc Cơ Ho là nhân vật lịch sử khá đặc biệt, hiện diện ngay từ những năm tháng đầu tiên từ khi cao nguyên này được khám phá (1893). Trong quá trình lịch sử, nhất là sau năm 1921 (khi người Pháp bắt đầu thực hiện đồ án quy hoạch Đà Lạt năm 1921 - 1923), người Cơ Ho ở Lạc Dương, Lâm Đồng đã được tiếp xúc, làm việc, phục vụ trong chính quyền của Pháp, sau đó là các cơ quan, tổ chức của Hoa Kỳ và chính quyền Sài Gòn. Số người này di cư sang Pháp, sau đó là Mỹ khi họ rời khỏi Việt Nam.

Sau ngày miền Nam hoàn toàn giải phóng (1975) và trong suốt thời kỳ bao cấp, quá trình di cư ra nước ngoài, có thể nói, bị gián đoạn do những nguyên nhân về chính trị, kinh tế, và xã hội của đất nước. Từ năm 1989 đến nay, quá trình di cư ra nước ngoài của đồng bào dân tộc thiểu số Cơ Ho ở huyện Lạc Dương đã được khởi động trở lại, với các loại hình di cư được mô tả trong các mục dưới đây:

\subsubsection{Di cu diện con lai với người Mỹ}

Nghiên cứu cho thấy từ những năm 1968 - 1973 một số phụ nữ người Cơ Ho ở Lạc Dương, Lâm Đồng đã làm thuê cho người Mỹ ở đồi Rađa (đỉnh núi Lang Biang), trong quá trình làm việc, từ thứ Hai những người phụ nữ này được xe đưa lên và thứ Bảy được đưa xuống. Qua tiếp xúc, giao lưu, họ đã có con với một số binh sĩ Mỹ và kết quả là những trẻ em lai ra đời. Theo các kết quả phỏng vấn sâu (PVS) của chúng tôi, ước tính có khoảng 16 người phụ nữ có con lai trong giai đoạn này. "Tiù khi Việt Nam đổi mói (1986) số con lai này được xuất cảnh đi Mỹ do người bố của chúng tìm lại. Trong nhũng năm tù 1990 - 1995 có 16 con lai di cu sang Mỹ’'(Cil, PVS, 2018).

Mặc dù chúng tôi không lượng định được số tiền gửi về, nhưng kết quả phỏng vấn sâu cho biết đến những năm 1995 số tiền con lai "gửi về nhiều", do được hưởng những chế độ chính sách an sinh xã hội của Chính phủ Hoa Kỳ: "Từ sau năm 1996 trở lại đây, các chế độ hỗ trọ bị cắt giảm, con lai phải tự kiếm sống, trình độ học vấn thấp, kinh tế chỉ đủ ăn, trong quá trình tiếp xúc với văn hóa Mỹ, đề cao giá trị cá nhân, mạnh ai nấy sống nên hầu nhu it có tiền gửi về quê nhà nũa" (Krajan, PVS, 2018).

\subsubsection{Di cu diện HO (Humanitarian Operation)}

HO là chương trình di cư cho những người từng phục vụ cho các cơ quan, tổ chức của Hoa Kỳ và chính quyền Sài Gòn giai đoạn trước năm 1975. Sau 1954 có một số người Cơ Ho ở Lạc Dương, Lâm Đồng làm việc cho các cơ quan, tổ chức của Hoa Kỳ và chính quyền Sài Gòn như đi lính, cán bộ hành chính... Sau năm 1975 những 
người này được đưa đi học tập, cải tạo. Chương trình $\mathrm{HO}$ do Chính phủ Mỹ hỗ trợ dành cho những đối tượng đã có thời gian học tập từ ba năm trở lên đi sang Mỹ. Chương trình này áp dụng từ 1989 và Chính phủ Việt Nam thông báo đến người dân và tiến hành làm những thủ tục cần thiết để được di cư diện HO. Từ những năm 1989 đến năm 2013 (sau đó chương trình bị gián đoạn), số người đi qua Hoa Kỳ theo diện HO tại địa bàn khảo sát ước tính khoảng 15 người.

\subsubsection{Di cu diện đoàn tụ gia đình (bảo lãnh)}

Từ sau năm 1992, theo quy định những người di cư diện HO có quyền bảo lãnh gia đình (cha mẹ, vợ con) sang định cư ở Mỹ, vì thế ước tính có khoảng 30 hộ gia đình trong huyện có bảo lãnh người thân ra nước ngoài. Tuy nhiên, trong quá trình này có xảy ra tình trạng di cư diện $\mathrm{HO}$ không thực chất (kết hôn giả, làm giả giấy tờ...). Chương trình này bị gián đoạn một thời gian, sau đó tiếp tục được phát triển cho đến ngày nay.

\subsubsection{Di cu ra nước ngoài học tập}

Quá trình phát triển kinh tế, xã hội đất nước và sự giao lưu văn hóa, giáo dục với Hoa Kỳ cũng đã thúc đẩy loại hình di cư ra nước ngoài học tập. Từ năm 2010 đến nay, có năm học sinh, sinh viên người Cơ Ho ra nước ngoài học tập. Họ chủ yếu là con em những gia đình khá giả, có điều kiện. Đáng chú ý số du học sinh này có quan hệ họ hàng với những người đã di cư qua Mỹ trước đó. Vì thế họ nhận được sự giúp đỡ ban đầu từ những người họ hàng của mình khi đến nơi ở mới. Đây được xem là số ít những người di cư trẻ có trình độ học vấn tương đối khá và năng động.

\subsubsection{Di cu theo diện kết hôn}

Theo nghiên cứu của chúng tôi, số lượng di cư ra nước ngoài theo diện kết hôn với người nước ngoài có số lượng lớn nhất trong số các loại hình di cư và có xu hướng gia tăng đáng kể theo thời gian. Kết quả khảo sát của chúng tôi cho thấy, đến nay đã có khoảng 70 người phụ nữ kết hôn với đồng bào của mình đã định cư ở Mỹ. Lý do để có loại hình di cư kêt hôn này hoàn toàn có thể lý giải một cách hợp lý và phù hợp với phỏng vấn sâu người dân rằng: "Số đàn ông người Co Ho đã định cu ở Mỹ có công ăn, việc làm ổn định và đưong nhiên ho mong muốn có vợ, con. Tuy nhiên, ở Mỹ không dễ gì lấy được vọ trong khi họ là người dân tộc thiểu số của Việt Nam qua Mỹ. Khi ho về nuớc, thăm gia đình ho hàng và thông qua mai mối, đặc biệt là vai trò của nguoòi cậu (nguoòi Co Ho đặc biệt coi trọng vai trò của nguời cậu trong gia đình) ho mong muốn có được người vọ là người đồng bào với mình" (Cil, Đa Gout, \& Krajan, PVS, 2018). Thông qua mạng lưới xã hội, số lượng người đàn ông Cơ Ho từ Mỹ về quê hương xứ sở của mình kết hôn với phụ nữ Cơ Ho ở huyện Lạc Dương, Lâm Đồng ngày càng gia tăng theo từng năm/tháng và đương nhiên, sau đó là các thủ tục bảo lãnh và di cư theo loại hình kết hôn có xu hướng gia tăng.

Theo kết quả phỏng vấn sâu từ một người Cơ Ho ở huyện Lạc Dương, tỉnh Lâm Đồng di cư qua Mỹ và đã hồi hương "Hiện tại có khoảng hơn 10,000 người dân tộc 
thiểu số ở Tây Nguyên đang sinh sống và làm việc tại Mỹ, trong đó người đồng bào thiểu số ở Lâm Đồng có khoảng hơn 1,000 người" (Cil, PVS, 2018).

Về nguyên nhân di cư ra nước ngoài của người Cơ Ho ở huyện Lạc Dương, tỉnh Lâm Đồng trong những năm gần đây gia tăng là do những yếu tố cơ bản như sau:

- Trước đây, thời bao cấp, đồng bào sinh sống và làm ăn tại chỗ, mặc dù đời sống còn nhiều khó khăn, nhưng sản lượng lúa, hoa màu, chăn nuôi trâu, bò cũng đủ trang trải cho đời sống vốn rất "an phận" của họ. Sau khi Việt Nam bắt đầu mở cửa, vận hành nền kinh tế theo cơ chế thị trường, cơ cấu kinh tế thay đổi, giống lúa địa phương dần dần bị mai một và không còn nữa, chăn nuôi giảm sút đáng kể, cà phê bấp bênh, một số người chuyển đổi nghề nghiệp qua dịch vụ, số ít làm công chức, viên chức nhà nước (công chức, viên chức trong cơ quan nhà nước, kiểm lâm, bảo vệ rừng, các khu du lịch... ), dù vậy, phần đông người dân vẫn loay hoay bươn chải cuộc sống, trong khi nền kinh tế thị trường tạo nên khoảng cách giàu nghèo và phân tầng xã hội đáng kể. Quan sát của chúng tôi thấy rằng người Kinh đến ngày một đông hơn và họ có nhiều cơ hội làm ăn với đồng bào các dân tộc thiểu số thông qua trao đổi hàng hóa, dịch vụ. Thực sự đời sống của người đồng bào Cơ Ho ở Lâm Đồng nói chung còn nghèo khó. Có thể nói đây chính là "lực đẩy" cho người di cư ra nước ngoài của người Cơ Ho ở huyện Lạc Dương, tỉnh Lâm Đồng;

- Sau khi Chính phủ Việt Nam và Chính phủ Hoa Kỳ ký kết chương trình nhân đạo $\mathrm{HO}$ cho phép những người làm việc trong các cơ quan, tổ chức của Mỹ và chính quyền Sài Gòn trước năm 1973 được di cư ra nước ngoài, thì một số người được đi qua Mỹ và cũng từ đây họ bắt đầu có những mối quan hệ qua lại với những người ở lại. Điều kiện sống, văn hóa Mỹ được họ chia sẻ qua lại, truyền bá văn hóa và lối sống Mỹ. Hơn nữa với nhu cầu tìm kiếm hôn nhân cùng đồng bào với mình. Người Cơ Ho ở huyện Lạc Dương, tỉnh Lâm Đồng cũng mong muốn qua Mỹ sinh sống chính là "lực hút" khiến cho họ di cư ra nước ngoài.

\subsection{Thực trạng di cư quốc tế của người Cơ Ho ở huyện Lạc Dương, tỉnh Lâm Đồng}

Lạc Dương là huyện vùng cao nằm ở phía Bắc của tỉnh Lâm Đồng có sáu đơn vị hành chính cấp xã (năm xã và một thị trấn), với tổng số dân là 26,692 người, trong đó người đồng bào dân tộc thiểu số chiếm khoảng $71.25 \%$ (Sử, 2018). Hầu hết người Cơ Ho di cư ra nước ngoài tập trung ở thị trấn Lạc Dương (khoảng 240 người) và xã Lát (có 10 người), các xã còn lại hầu như không có người di cư ra nước ngoài. Kết quả phỏng vấn sâu và thảo luận nhóm những người được xem là chuyên làm công việc giấy tờ, thủ tục di cư ra nước ngoài cho đồng bào dân tộc thiểu số Cơ Ho ở huyện Lạc Dương, tỉnh Lâm Đồng cho thấy: 
- Toàn bộ những hộ gia đình có người thân di cư ra nước ngoài có mức sống từ trung bình và khá giả trở lên. Một nghiên cứu khác của Trần (2005) cũng cho thấy mức sống của hộ gia đình trước và sau khi con gái lấy chống Đài Loan có sự thay đổi đáng kể: Giảm hộ rất nghèo và nghèo (126 còn 6 và 261 còn 52), tăng hộ trung bình, tương đối khá và khá giả (lần lượt là 191 lên 272,43 lên 238 và 10 lên 66);

- Những hộ gia đình có người di cư ra nước ngoài có quan hệ là anh/em bên vợ, con đẻ, con dâu/rể, bố/mẹ vợ... Nơi di cư đến là Mỹ, chiếm tỉ lệ tuyệt đổi $100 \%$ cộng đồng được nghiên cứu, trong đó có một số ít di cư bất hợp pháp, vượt biên trái phép qua Campuchia và Thái Lan, sau đó qua Mỹ. Giới tính người di cư, giai đoạn đầu từ năm 1990 đến khoảng năm 2010 chủ yếu là nam; Từ năm 2010 đến nay di cư chủ yếu là nữ do loại hình di cư theo hình thức hôn nhân. Về thời gian di cư: Ngoài số ít những người theo Pháp, Mỹ trước 1975, còn lại đa số người di cư qua Mỹ từ khoảng 1990 đến nay với các loại hình như phân tích ở trên, có người di cư đã gần 30 năm. Nhìn chung, tình hình di cư không tăng đều qua các năm từ 1990 đến nay, nhưng có xu hướng tăng trong những năm trở lại đây. Số lượng lớn những người di cư ra nước ngoài, trong số này chủ yếu trong độ tuổi học sinh, sinh viên và kết hôn với người đồng bào Cơ Ho đã ra nước ngoài sinh sống. Về độ tuổi: Chủ yếu trong độ tuổi lao động, tức từ 15 đến 60 tuổi. Số ít là con nhỏ theo ba mẹ, hoặc người từ 60 tuổi trở lên theo con cái đoàn tụ gia đình;

- Phần lớn nghề nghiệp trước khi di cư ra nước ngoài là nông nghiệp, có một vài người có nghề nghiệp khác như bác sĩ, giáo viên (được đào tạo trước Giải phóng). Sau khi di cư qua Mỹ có sự thay đổi nghề nghiệp rõ rệt, phần lớn họ tham gia các ngành nghề dịch vụ (các nghề làm tóc, làm móng $($ nail $))$, làm cho các dịch vụ này, rất ít người có đủ trình độ cũng như vốn để mở tiệm riêng mà chủ yếu làm thuê. Những người di cư ra nước ngoài cũng thường xuyên liên lạc với gia đình của mình ở quê nhà, nhất là trong điều kiện hiện nay với sự liên lạc qua mạng xã hội như Facebook, Zalo... Phỏng vấn sâu vài trường hợp cũng cho biết sự liên lạc về gia đình ở mức độ thường xuyên/tuần;

- Việc liên lạc thường xuyên giúp người ta chia sẻ thông tin, tăng cường sự hiểu biết, trao đổi tâm tư tình cảm, giúp kết nối và tạo mạng lưới xã hội. Điều này ảnh hưởng quan trọng trong đời sống của người di cư và gia đình họ. Kết quả nghiên cứu còn cho thấy thông qua việc liên lạc với gia đình và kết nối, chia sẻ với cộng đồng, có rất nhiều trường hợp di cư theo diện hôn phu/hôn thê.

Có thể nói, trong quá khứ, cộng đồng người Cơ Ho ở huyện Lạc Dương, tỉnh Lâm Đồng luôn diê̂n ra quá trình du canh, du cư. Từ khi Pháp, sau đó là Mỹ đến, quá trình di cư ra nước ngoài bắt đầu diễn ra. Khi người Pháp rút khỏi Việt Nam năm 1954, một bộ phận người Cơ Ho (làm việc cho Pháp) đã di cư theo người Pháp và sinh sống tại Pháp hầu như không có mối liên lạc gì với quê nhà. Kể từ khi người Mỹ đến và đi, 
các hình thức di cư đã diễn ra: Di cư diện con lai, di cư diện HO, di cư diện bảo lãnh, di cư du học sinh, và di cư diện kết hôn. Có thể nói, do các chính sách của Việt Nam cho phép người Cơ Ho qua Mỹ theo chương trình nhân đạo được ký kết và do sự chênh lệch về điều kiện sống của nơi đến và nơi đi đã thúc đẩy di cư, và hệ thống mạng lưới xã hội đã hỗ trợ giúp đỡ những người ở lại được di cư ra nước ngoài, do sự lựa chọn của những người di cư khi thấy những điều kiện sinh sống tốt hơn. Phần lớn những người trước khi di cư làm nghề nông nghiệp (trồng trọt, chăn nuôi) và sau khi di cư ra nước ngoài làm công nhân, làm các dịch vụ (làm nail là chủ yếu). Sự phát triển của công nghệ thông tin đã kết nối người di cư ở nước ngoài với gia đình trong nước giúp chia sẻ thông tin, tăng cường sự hiểu biết, trao đổi tâm tư tình cảm, tạo dựng mạng lưới xã hội. Những nhân tố này lại tiếp tục phát huy tác dụng, góp phần hình thành và phát triển động lực di cư trong những người ở lại, cũng như hối thúc người di cư quay về thăm gia đình, gặp gỡ họ hàng, quê hương. Có thể nói sự ảnh hưởng của yếu tố văn hóa - xã hội làm phong phú thêm bức tranh di cư của đồng bào dân tộc Cơ Ho tại huyện Lạc Dương, tỉnh Lâm Đồng.

\subsection{Vai trò của di cư quốc tế trong đời sống người Co Ho ở huyện Lạc Dương, tỉnh Lâm Đồng}

Kết quả nghiên cứu cũng cho thấy, trước năm 2010, hầu hết các gia đình nhận được tiền/quà từ người thân ở nước ngoài gửi về. Tuy nhiên, vì lý do tế nhị (người ta ngại nói về tiền và quà được gửi về) nên có một số phỏng vấn sâu, nhưng khó xác định được chính xác lượng tiền gửi về. Trong khi đó, theo tính toán của Ngân hàng Thế giới (World Bank - WB) thì:

WB ước tính năm 2017 kiều hối Việt Nam đạt 13.8 tỉ USD. Vừa qua, WB đưa ra dự báo trong năm 2018 dự kiến kiều hối là 15.9 tỉ USD, đưa Việt Nam tiếp tục nằm trong top những nước nhận kiều hối lớn nhất năm nay. Kiều hối đóng góp 6.6\% GDP Việt Nam (Dương, 2018).

Khi phỏng vấn một người Cơ Ho di cư qua Mỹ và trở lại tại địa bàn nghiên cứu, chúng tôi được biết, lượng tiền trung bình một hộ gia đình khi qua Mỹ thường gửi về cho gia đình họ ở quê nhà từ 100 USD đến 200 USD/năm, chủ yếu là vào dịp lễ, tết, hiếu hỉ hoặc khi gia đình có người ốm đau. So với những thông tin thu thập từ người khác, chúng tôi nhận thấy rằng có sự khác nhau đáng kể. Nguyên nhân này được lý giải như sau: "Trước đây tù̀ khoảng nhũng năm 1991 đến năm 1996 luợng tiền gửi về khá nhiều qua nhiều hình thức khác nhau (bưu điện, gửi qua người thân về nuớc...) thuờng là khoảng bốn đến năm nghìn đô, thậm chí là chuc nghìn đô về cho gia đình ở quê nhà trong một quý hoạc một năm. Tuy nhiên, trong nhũng năm gần đây, tiền chuyển về it hơn, thậm chí là không chuyển do kinh tế của nhũng người di cu bên Mỹ khó khăn, các chính sách hỗ trọ̣ của Mỹ đối với nhóm người này bị cắt giảm" (Cil, PVS, 2018).

Trong nghiên cứu này, ngoài việc phân tích vai trò của di cư ra nước ngoài trong đời sống gia đình, chúng tôi còn phân tích xem vai trò của di cư trong cộng đồng ở các khía cạnh đóng góp vào trong các hoạt động của cộng đồng như làm đường sá, nhà thờ, hay các lễ hội cộng đồng. Kết quả phỏng vẩn sâu của chúng tôi cho biết, khi trong cộng 
đồng có những hoạt động liên quan đến cộng đồng như vận động góp tiền xây dựng, sửa chữa nhà thờ, đường sá thì những người đứng ra tổ chức, vận đồng người ở nước ngoài đóng góp và gửi tiền về hoặc trong cộng đồng có những già làng, người cao tuổi mừng thọ thì những người nước ngoài sẵn sàng ủng hộ. Hoạt động này thường diễn ra hàng năm, trung bình một năm có khoảng năm đến 10 lễ mừng thọ. Một hoạt động khác cũng đáng chú ý đó là đóng góp tiền cho các hoạt động của nhà thờ, hầu như năm nào cũng có, nhất là dịp Giáng sinh. Tất cả những người di cư ra nước ngoài đều theo tôn giáo (Tin Lành và Thiên Chúa giáo).

Một vấn đề khác nữa là tình trạng bảo lãnh người trong gia đình ra nước ngoài, thông qua hình thức bảo lãnh, hôn phu/hôn thê với những người đã ra nước ngoài trong cộng đồng người Cơ Ho đã, đang diễn ra và có chiều hướng gia tăng trong những năm gần đây. Qua quan sát và phỏng vấn sâu, chúng tôi biết được có tình trạng gia đình người Cơ Ho ở huyện Lạc Dương, tỉnh Lâm Đồng tìm mọi cách cho con cái của họ qua Mỹ (giả giấy tờ, kết hôn giả...) và trong vài ba năm đầu tiên qua Mỹ, gia đình bên này phải gửi tiền cho con cái của họ bên Mỹ sinh hoạt và học tập. Về mạng lưới quan hệ xã hội của cộng đồng người di cư đối với người ở lại là rất cao và tạo nên một số quan hệ xã hội đa dạng khác, ví dụ như mai mối để kết hôn hoặc làm giả giấy tờ để đi nước ngoài. Thậm chí khi không đủ điều kiện để di cư thì tổ chức đưa người vượt biên trái phép. Một số người Cơ Ho mong muốn được đi Mỹ sinh sống, vì cứ nghĩ rằng nơi đó có cuộc sống tốt đẹp hơn, sung sướng hơn nên có hiện tượng người ở bên này lo tiền cho những người bên Mỹ để làm các thủ tục cần thiết để bảo lãnh ra nước ngoài, có nhiều trường hợp do sự kiểm soát chặt chẽ của các cơ quan chức năng từ phía Mỹ và Việt Nam nên cuối cùng họ vẫn không được đi. Những ảnh hưởng tiêu cực này tác động nhiều ít đến đời sống của cộng đồng nơi xuất cư.

Phỏng vấn sâu của chúng tôi với người di cư ra nước ngoài và đã trở về (hiện đã có năm trường hợp sau khi đi ra nước ngoài rồi hồi hương). Theo đó, "Hầu hết họ qua bên Mỹ có cuộc sống khá giả hơn so với quê nhà, xã hội Mỹ mà. Tuy nhiên, ho phải làm việc vất vả, các công việc nặng nhọc và phải làm thuê - "làm nail". Tính tôn trọng về mặt xã hội không cao, vì họ là người dân tộc thiểu số, trình độ không có, phải tụ buoon chải làm ăn, sư giúp đõ mang tính cộng đồng nhu ở bên quê nhà không có, "mạnh ai nấy sống" (Krajan, PVS, 2018). Đây cũng chính là lý do người này quyết định trở về với núi rừng Lang Biang. Dù vậy, người trả lời phỏng vấn cũng thừa nhận, có những cha mẹ có suy nghĩ sâu xa và cho rằng "hi sinh đời bố, củng cố đời con" để cho con trẻ có cơ hội học hành và làm ăn bên Mỹ nên họ chấp nhận cực khổ và xa quê vì con cái. Sau khi thu xếp cho con cái ổn định nơi ăn, chốn ở, trường học và việc làm thêm, người này trở về Việt Nam vì theo ông Việt Nam là "sướng nhất".

Ngày nay với sự phát triển của công nghệ thông tin, người di cư ra nước ngoài với những người ở lại dễ dàng kết nối thông tin, chia sẻ các vấn đề về cuộc sống thông qua điện thoại, Internet, Facebook, Zalo... qua đó họ kết nối giữa gia đình này với gia đình khác, những gia đình có người di cư và những gia đình không có người di cư. Hơn nữa, hầu như hàng năm những người di cư ra nước ngoài đều về thăm quê hương, mang theo văn hóa, lối sống, vật dụng, đồ dùng về cho người ở quê nhà, họ trao đổi, chia sẻ, mong muốn được giúp đỡ đồng bào của họ qua sinh sống với họ. Từ đó có những cuộc 
hôn nhân nhanh chóng để có sự bảo lãnh đi ra nước ngoài và số người người Cơ Ho từ nước ngoài về quê nhà tìm vợ, chồng cho mình ngày càng gia tăng.

\section{KẾT LUẬN}

Từ khi đất nước được đổi mới đến nay, quá trình công nghiệp hóa, hiện đại hóa và mở cửa hội nhập quốc tế, thu hút đầu tư nước ngoài đã dẫn đến những tác động sâu sắc trong phát triển kinh tế, văn hóa, và xã hội. Di cư trong nước và quốc tế bên cạnh những mặt tích cực cũng đem lại một số hệ lụy xã hội cần được xem xét nghiên cứu để thực hiện mục tiêu phát triển bền vững.

Di cư là một hiện tượng kinh tế - xã hội gắn liền với đặc điểm lịch sử phát triển của mỗi quốc gia. Các nghiên cứu trên bình diện quốc tế cũng như trong nước đã thừa nhận khác với các quá trình dân số khác như: Sinh đẻ và tử vong, di cư là hiện tượng không dễ đo đếm bởi các yếu tố phức tạp, khó đo lường về lượng người nhập, xuất cư, thời gian di cư, các hình thức di cư cũng như những ảnh hưởng, tác động của nó đối với nơi đến và nơi đi.... Tuy nhiên, chính đặc trưng đó cũng đặt ra những yêu cầu cao về phương pháp và kỹ thuật cho những nghiên cứu di cư quốc tế.

Nghiên cứu này có những hạn chế trong việc nghiên cứu định lượng tổng thể hộ gia đình ở lại quê nhà và khảo sát, đo lường hay quan sát trực tiếp đời sống của những người Cơ Ho ở nước ngoài. Những thông tin thu được đều thông qua quan sát, thảo luận nhóm nhỏ, phỏng vấn sâu từ những người hồi hương và người làm hồ sơ, giấy tờ cho người di cư ra nước ngoài. Hơn nữa cũng chưa nhận diện đầy đủ những mặt trái của quá trình di cư đối với nơi đến và cuộc sống của họ khi xa xứ.

Qua nghiên cứu, chúng tôi cho rằng những ảnh hưởng của di cư đến đời sống người Cơ Ho ở Lạc Dương qua các khía cạnh kinh tế, mức sống, kiều hối, không rõ rệt. Đời sống của các hộ gia đình và cá nhân có người di cư ra nước ngoài đa số ở mức trung bình, khá giả nhưng không thay đổi nhiều sau di cư. Tuy nhiên, tình trạng di cư ra nước ngoài trong đời sống người Cơ Ho ở Lạc Dương, tỉnh Lâm Đồng gia tăng theo thời gian. Các loại hình di cư diện con lai, $\mathrm{HO}$ không còn nữa, nhưng những loại hình di cư thuộc diện bảo lãnh (qua các hình thức hôn phu, hôn thê, bảo lãnh người thân trong gia đình) có xu hướng gia tăng qua từng năm, thậm chí theo từng tháng. Thiết nghĩ, cần giúp người dân nhận thức rõ hơn, đúng đắn hơn về tình hình di cư ra nước ngoài. Bởi lẽ, bên cạnh những mặt tích cực của quá trình di cư quốc tế như các nghiên cứu đã chỉ ra, những cuộc hôn nhân được thực hiện nhanh chóng để được ra nước ngoài, trong khi người di cư chưa có sự chuẩn bị về văn hóa, lối sống, nghề nghiệp và các điều kiện khác rất dễ đẩy người di cư đương đầu với những mất mát không thể bù đắp được. Việc di cư ra nước ngoài, đặc biệt là đối với những ông/bà, cha mẹ già, người lớn tuổi qua đoàn tụ gia đình như là cách để hưởng những năm tháng cuối đời có thể không phải là biện pháp tốt nhất. Thực tế, một công trình nghiên cứu lớn về người Việt Nam ở Mỹ đã chỉ ra những ảnh hưởng tai hại do kéo dài tình trạng chán nản, lo lắng nhiều, xung đột trong hôn nhân, xung đột giữa các thế hệ và nhiều vấn đề tình cảm khác (Thomas, 1998). 


\section{TÀI LIỆU THAM KHẢO}

Cục lãnh sự - Bộ Ngoại giao, \& IOM - OIM. (2017). Hồ sơ di cu Việt Nam 2016. Hà Nội, Việt Nam: Cục lãnh sự - Bộ ngoại giao.

Cục Lãnh sự - Bộ Ngoại giao, Liên minh Châu Âu, \& Tổ chức di cư Quốc tế IOM. (2011). Báo cáo tổng quan về tình hình di cu của công dân Việt Nam ra nước ngoài. Hà Nội, Việt Nam: Cục Lãnh sự - Bộ Ngoại giao.

Đặng, A. N. (2009). Xã hội học dân số. Hà Nội, Việt Nam: NXB. Đại học Quốc gia Hà Nội.

Dương, N. (2018). Người lao động. Được truy lục từ https://nld.com.vn/kinh-te/wbkieu-hoi-du-kien-189-ti-usd-nam-2018-20181220165711118.htm

Perruchoud, R., \& Cross, R. J. (2011). Thuật ngũu về di cu. Hà Nội, Việt Nam: Tổ chức Di cư Quốc tế.

Sử, H. T. (2018). Báo cáo kết quả thực hiện công tác dân vận chính quyền năm 2018. Lâm Đồng, Việt Nam: Uỷ ban Nhân dân huyện Lạc Dương.

Thomas, T. (1998). Vấn đề người cao tuổi Việt Nam ở Úc. Trong Việt Nam học - Kỷ yếu Hội thảo Quốc tế lần thư 1 (tr. 287). Hà Nội, Việt Nam: NXB. Đại học Quốc gia Hà Nội.

Trần, T. K. X. (2005). Nguyên nhân phụ nữ Đồng bằng sông Cửu Long kết hôn với người Đài Loan (nghiên cứu tại Cần Thơ, Tiền Giang, Đồng Tháp, Hậu Giang, An Giang, và Vĩnh Long). Tạp chí Xã hội học, (1), 73-84. 